\title{
ASSESSMENT OF HISTORICAL BIO-INDEX CHANGES IN RURAL AREAS IN SOUTHERN POLAND - CASE STUDY
}

\author{
Barbara PRUS, Institute/department of Spatial Development and Landscape Architecture, Faculty of Environmental Engineering and \\ Land Surveying, Agricultural University in Kraków, Address: Balicka str. 253c, 30-149 Kraków, Poland; plan.zaoczne@gmail.com \\ (corresponding author) \\ Stanisław BACIOR, Institute/department of Geodesy, Cadastre and Photogrametry, Faculty of Environmental Engineering and Land \\ Surveying, Agricultural University in Kraków, Address: Balicka str. 253a, 30-149 Kraków, Poland; stanislaw.bacior@ gmail.com \\ Małgorzata DUDZIŃSKA, Institute/department of Geospatial Analysis and Cadastre, Faculty of Geodesy, Geospatial and Civil \\ Engineering, University of Warmia and Mazury in Olsztyn, Address: Prawocheńskiego str. 15, 10-719 Olsztyn, Poland; \\ gosiadudzi@uwm.edu.pl
}

\begin{abstract}
Intensity of land use could be considered as an indicator of rate of anthropogenic impact on landscape (CAI) and the coefficient of ecological stability (CES). These two bio-indexes are based on the land use categories. The CAI coefficient is the ratio of the sum of percentile areas of land characterized by considerable human impact in relation to the sum of percentile areas of lands with low or none anthropogenic pressure. The CES index describes the structure of land use in one unit according to land use categories weighted by given coefficients. The calculation of the complex integral index enables to know the potential of the environment, i.e. a natural resource reserve with a structure that allows self-regulation of ecosystems and expresses the environment's resistance to bearing anthropogenic loads. The aim of the study is to analyze the historical land use changes (in the period of 1845-2016) in rural areas of Southern Poland using bio-indexes such as the anthropogenic impact on landscape (CAI) and the coefficient of ecological stability (CES). The analysis led to the conclusion about the strong dynamics of changes during this period which is largely due to the growth of the percentile areas of lands with considerable human impact especially after the historical transformation in 1989 in Poland. At the same time, the attention should be paid to the land use changes as an effect of growing suburbanization. The results of the study can be used by public authorities, citizens and governing bodies to form a system of measures to calculate environmental potential and modelling changes which ensure the environmental protection and sustainable development of rural areas.
\end{abstract}

Keywords: anthropogenic pressure, dynamics of land use changes, environmental potential, environment's resistance, rural areas, sustainable development

\section{INTRODUCTION}

\section{Importance of the problem}

Modifications of land use result in significant changes in the range of natural environment including natural resources and environment's renewable sources i.e. water, air, soil, flora and fauna. The process of modifications depends on changing political, cultural, institutional and economic conditions and, most of all, it depends on technical progress. According to Bičik, changes in land use in the last 150 years are a sign of "heterogeneization of once homogenous system (Bičik, 1991, p.77)" under the influence of varying functions, changing importance and needs (Mather 2002). The human pressure on natural conditions is different in changing localities. Two last centuries resulted in Poland in dynamic socioeconomic changes as well as civilizational and technical progress including the way of land use at rural areas but also economic, social, cultural and architectural transformations (Sokołowski ,1999). The area of suburban zones is increasing, above all (Poniży, 2008; Springer, 2013). The phenomenon of expansion of urban infrastructure on rural areas in Poland was already observed at the beginning of the 1980. (Bartkowski, 1981). Naturally, more suitable conditions mean more significant anthropogenic pressure on landscape. Suitable conditions mean more arable land, permanent cultures and build-up areas. Worse conditions are natural for more grassland and forests. Some regions are suitable for agriculture and are intensified, other areas are grassing over and in some places urban function was preferred, especially in close vicinity of cities.

The analyzed period in Polish history, according to land use changes, can be divided in several stages of social development (Poławski, 2009). In the years 1848-1918, the South Poland was a part of The Austro-Hungarian Monarchy. This region was characterized by the agricultural nature. On the other hand, the people who resided in this area were very

Copyright (C) 2017 The Authors. Published by Aleksandras Stulginskis University. This is an open-access article distributed under the terms of the Creative Commons Attribution License (CC-BY 4.0), which permits unrestricted use, distribution, and reproduction in any medium, provided the original author and source are credited. 
poor. The occupants did not care for technical and industrial development of this area taking only profits in the form of collecting taxes. Creating the State of Poland in the autumn 1918 is the beginning of significant influence of industrialization and modernization till the WW2. This period called the interwar one covers the years 1919-1938. In the years 1939-1945 - there were no radical changes in land use structure but the territory was influenced by the outbreak of WW2 and plundering politics of the invaders. The years 1946-1988 - the period of socialism was characterized by the change of rural politics with a focus on social property whereas smaller demand for economical effectiveness and environmental protection can be noticed. The period of 1989-2004 is a transformation period and return to free market and technical development but also grassing over and afforestation. The years 2005-2016 is the time of changing of agricultural conditions after Polish EU accession.

The aim of the article is to analyze the historical land use changes (in the period of 1845-2016) in rural areas of Southern Poland using bio-indexes such as the anthropogenic impact on landscape (CAI) and the coefficient of ecological stability (CES).

\section{Literature Review}

Land use is changing because it is the interaction in space and time between biophysical and human dimensions (Veldkamp and Verburg, 2004; Kabrda, 2004). As a result of variable socioeconomic (Long et al. 2007), environmental (Schaldach et al. 2011), political, technological or cultural conditions (Bürgi et al. 2010), these alterations drive global changes in the environment, for example water, soil, air quality, climate (Kalnay and Cai, 2003; Bürgi et al. 2005) or ecosystem (Lamblin et al. 2000; Louca et al. 2015). There have been significant regional differences in land use changes which result from changing human pressure on nature and natural and social conditions of regions or localities.

The process of land enfranchisement was a significant factor influencing land use in the XIX century. In the Austrian partition, the change of agrarian structure consisted in fragmentation of agricultural farms and the results of this process can be still visible in the form of a great number of small farms and so called a land chessboard (Poławski, 2009). Characteristic for southern Poland, the mosaic of arable lands, grassland and forests together with dispersed buildings create a traditional agricultural landscape (Staniak, 2009, Baran-Zgłobicka and Zgłobicki, 2012). Such state of land use results from the specific landform and also overlapping of the results of social interests of land owners, citizens, local governments and also planners and architects (Eiter et al. 2014). The land chessboard is a cultural mosaic that contains the evidence of human presence and their way of life being characterized by rich natural variety (Andrzejewski and Weigle, 2003). Political socio-economic transformations and also intensification of agriculture form the reason of introducing new crops and thereby changes in land use (Bürgi et. al 2005) and the traditional mosaic of lands (BaranZgłobicka, Zgłobicki, 2012). On the other hand, transformations in land use impact the changes that take place in the natural environment (Bucała and Starkel, 2012; Bański and Mazur, 2016; Pohl, 1978).

In Poland, land-use changes are more significant after the historical transformation from 1989, in the age of progressing globalization and economic integration (Hernik et al. 2013; Zydroń and Hausa, 2010). In some locations, urban function was preferred whereas in the other ones agricultural function was concentrated.

\section{METHOD OF RESEARCH}

The analysis of changes in land use was performed by comparing the analyzed area in historical cartographic materials elaborated within the Franciscan Cadastre (1845) and current area of farmlands provided by Databases of Topographic Objects, so called BDOT10k (2016). The comparing process was possible to perform because the AustroHungarian cadastral maps are comparable to newer sources (Harvay et al. 2014). The historical ways of land use were collected on the basis of chromatic maps of the Austrian cadastre, so called Viennese, gained from the National Archive in Krakow. The obtained scans of cadastral maps for the analyzed objects (Kaszów and Kryspinów) were calibrated and then the target coordinate system was specified and lots' vectorization was performed determining their number and the kind of land use for each of them. In Kaszów, 4,400 objects (plots) and in Kryspinów 1,335 objects (plots) during vectorization were obtained. The layers from vectorization were checked in terms of topology correctness. The prepared layers were used for spatial analyses. The state of land use in 2016 was obtained from the Databases of Topographic Objects on the basis of farmlands classification according to the Regulation on lands and buildings record (Regulation... 2001).

Anthropogenic influence (according to Bičík (1991)) which presents six main kinds of coverage and the ratio of the sum of percentile areas of lands characterized by considerable human impact (arable land, built-up areas, remaining areas) in relation to the sum of percentile areas of lands not burdened with anthropogenic pressure (permanent grassland, forest areas, water areas) was calculated - as presented in the formula (1):

$$
C A I=\frac{A L+B A+R A}{P G+F A+W A}
$$

where:

$$
\begin{aligned}
& \mathrm{CAI} \text { - anthropogenic influence coefficient } \\
& \mathrm{AL} \text { - arable land [\%] } \\
& \mathrm{BA} \text { - build-up areas [\%] } \\
& \mathrm{RA} \text { - remaining areas [\%] }
\end{aligned}
$$


$\mathrm{PG}$ - permanent grassland, pastures [\%]

FA - forest areas [\%]

$\mathrm{WA}$ - water areas [\%].

Permanent grassland includes meadows and pastures. Remaining areas represent various areas for transport, bare or non-fertile land, rocks, bushes and other fallow, non-cultivable or non-used lands.

According to the assumptions, the calculated anthropogenic influence coefficient (CAI) also presents the environment's potential which can be illustrated by the energy input that should be invested to transform natural resources of the environment so that persistence of natural conditions at a certain area was changed. The character of these resources is changed most frequently from the natural to anthropogenic one (Cegielska et al. 2017). So, it can be assumed that this coefficient will illustrate the rate of transformations of the primary environment. The greatest interference in the environment will cause the entire transformation of the primary landscape into the anthropogenic one.

The coefficient of ecological stability (CES) - which is an aggregated indicator describing the structure of land use in one number - was also used for the evaluation of use changes. It shows the share of eight basic land use categories of the area weighted by given coefficients and expresses the ecological stability, intensity of use by society as in formula (2):

$$
C E S=\sum_{i=1}^{n=8} c e s_{i} \cdot a_{i}
$$

where:

$\boldsymbol{c e s}_{i}$ - the coefficient for land use category (arable land 0.14; permanent cultures 0.34; meadows 0.62; pastures 0.68; forested areas 1.00; water areas 0.79 ; build-up areas 0.00 ; remaining areas 0.14 )

$\boldsymbol{a}_{i}-$ share of land use category in the analyzed unit (\%).

The CES index fluctuates from 0 to 100. The higher value of CES, the ecologically more stable unit, which means the area less colonized by the community, is closer to the natural state. CES coefficient could be used as an indicator of land use intensity or of anthropogenic pressure on the environment or else as a rate of nature's conversion by human society.

Intensity of land use could be considered as an indicator of the anthropogenic coefficient (CAI) or the coefficient of ecological stability (CES). These two indexes (bio-indexes) base on land use categories (the kind of coverage). The CAI coefficient is the ratio of the sum of percentile areas of land characterized by considerable human impact in relation to the sum of percentile areas of lands with low or none anthropogenic pressure. The CES index describes the structure of land use in one unit according to land use categories weighted by given coefficients.

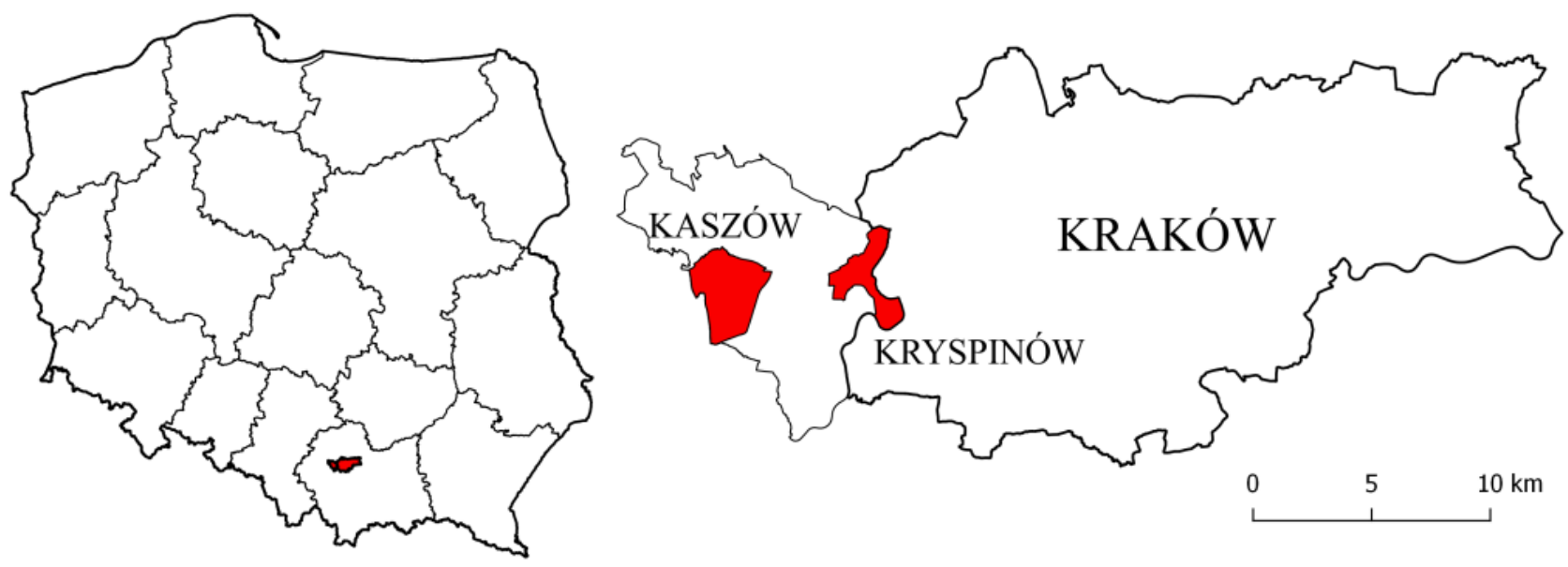

Figure 1. Location of analysed objects. Source: own study.

The analyzed objects - Kryspinów and Kaszów - are located in Southern Poland, Małopolska, in close proximity of Krakow on its western side and are placed in the Krakow district. The analyzed objects were chosen so as to be situated in more and more distant zones from Krakow city (Fig. 1). The analysis allowed to research the change rate of land cover over 168 years as well as to test evaluation of distance to Krakow at the direction and dynamics of changes of land use at agricultural areas. The first - Kryspinów - adjoins directly to Krakow. The distance of Kaszów location is 6 km counting from the current western administrative borders of Krakow city. Until recently, agricultural crops produced at the area of two mentioned places were covering the needs of not only local communities but they were also transported to Krakow and sold there on market places. 


\section{RESULTS AND DISCUSSION}

The conducted analyses and calculations concerning historical changes of land use as CAI (anthropogenic influence coefficient) and CES (coefficient of ecological stability) indexes at the area of two places located near Krakow indicate significant changes which took place in the way of land use over almost seventeen decades. The greatest changes in land use concerned in cases of both places most of all the lands used agriculturally and also the built-up and urbanized areas (Fig. 2., Fig. 3.).

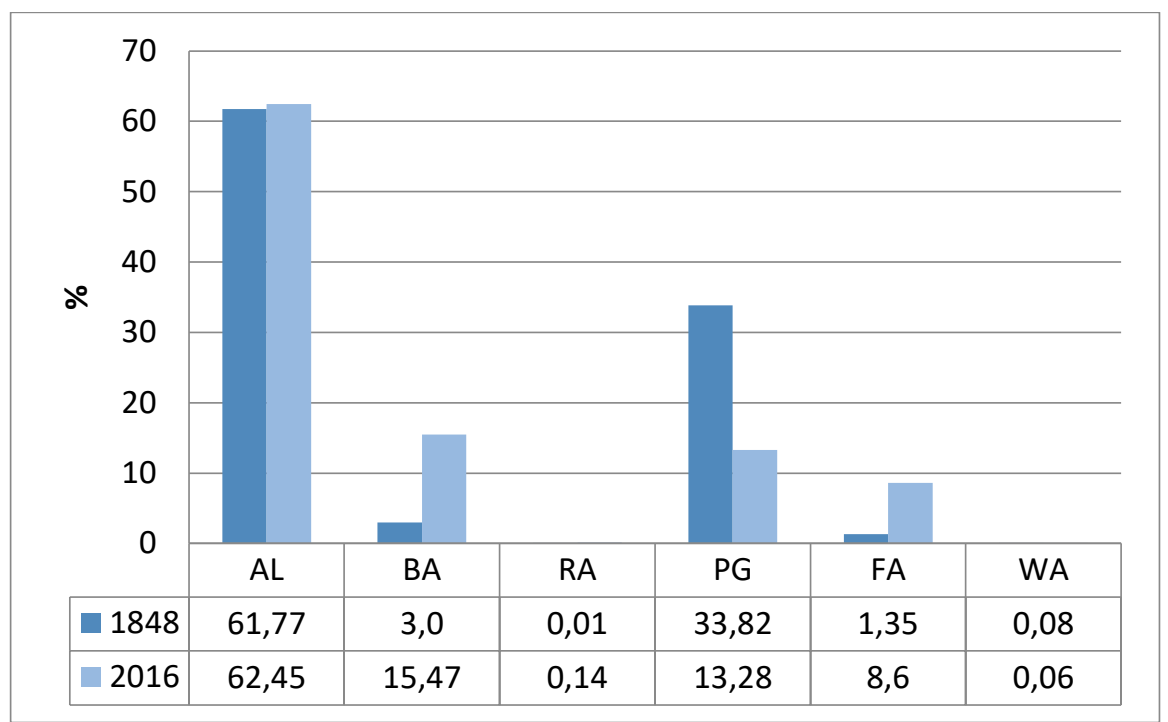

Figure 2. Graphic presentation of the ways of land use in the years 1848 and 2016 in Kaszów. Descriptions as in the formula (1). Source: own study.

However, it is worth to notice that the direction of changes was different in both locations. In case of Kaszów, the area of arable lands noted in 2016 was comparable to this from before 170 years. Only the area of grassland decreased in favour of built-up areas and forests (Fig. 2). This direction of changes is visible in the value of obtained CAI and CES indexes (Table 1). In case of Kaszów, CAI increased almost by the double i.e. from the value 1.84 to 3.56 which means the increase of anthropogenically transformed area in relation to the lands not burdened with anthropogenic pressure. The value of CES index indicates the decrease of ecological stability of Kaszów place during the surveyed period. This result was certainly influenced by the fact that the presented coefficient is based on the assumption that the arable lands are included into the category of the areas which are transformed anthropogenically.

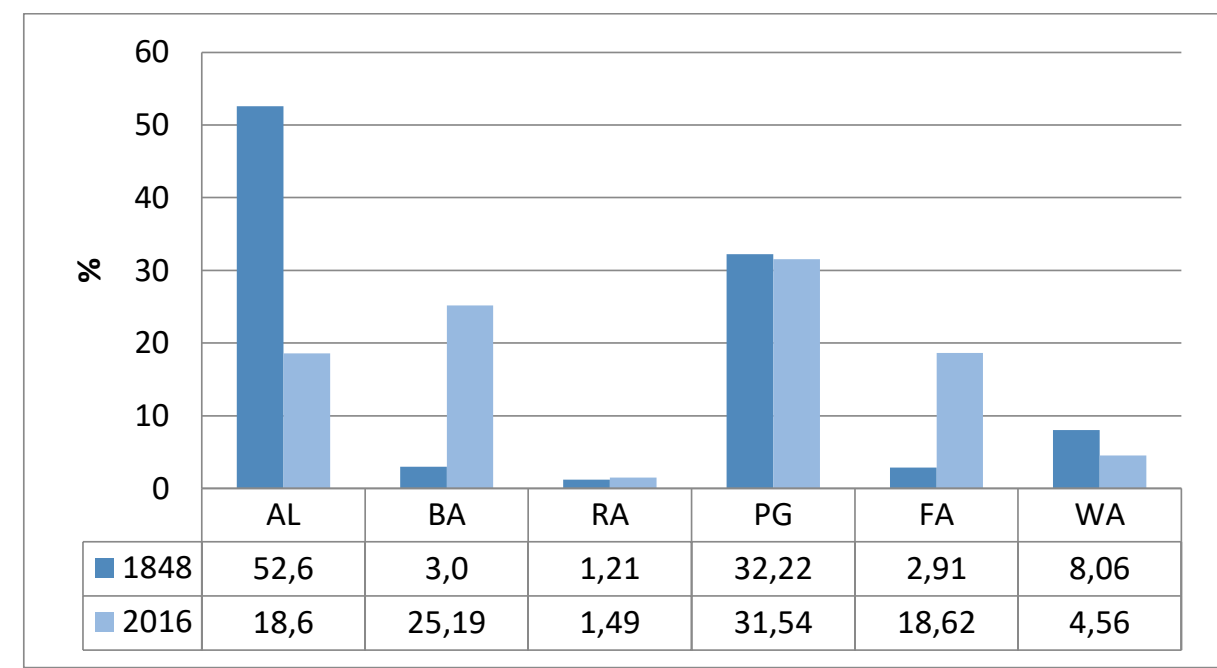

Figure 3. Graphic presentation of land use in the years 1848 and 2016 in Kryspinów. Descriptions as in the formula (1). Source: own study.

The greatest changes of land use in the years 1848-2016 in Kryspinów concerned the area of arable lands, builtup areas and forests (Fig. 3). The area of the arable lands decreased over these years by 34\%. On the other hand, the area of built-up area increased by slightly over $22 \%$. The share of forests increased by $15.7 \%$. This direction of changes in land use caused the decrease of CAI index from the level of 1.32 to 0.83 which indicates the higher increase of lands not burdened with anthropogenic pressure in relation to the areas defined as anthropogenic ones. 
Table 1. Bio-indexes CAI and CES in Kaszów and Kryspinów

\begin{tabular}{|c|c|c|c|c|}
\hline \multirow{2}{*}{ bio-index } & \multicolumn{2}{|c|}{ Kaszów } & \multicolumn{2}{c|}{ Kryspinów } \\
\cline { 2 - 5 } & $\mathbf{1 8 4 8}$ & $\mathbf{2 0 1 6}$ & $\mathbf{1 8 4 8}$ & $\mathbf{2 0 1 6}$ \\
\hline CAI & 1.84 & 3.56 & 1.32 & 0.83 \\
\hline CES & 32.47 & 26.67 & 38.07 & 47.14 \\
\hline
\end{tabular}

\section{Source: own study}

This direction of transformations is also confirmed by the value of CES index which increased by almost 10 units and means the increase of ecological stability of Kryspinów. The increased area of forests together with almost unchanged area of farmland and simultaneous high decrease of percent of arable lands in the total area of the place can be responsible for this state.

Numerous studies around the world have attempted to understand the processes of changes in land use structure (Poławski, 2009; Bičík I. et al. 2012; Bičík I. et al. 2014; Noszczyk et al. 2017). These changes can be also expressed by the indexes that describe the state and potential of the natural environment (Bičík I. et al. 2012; Kabrda, 2004). The environment changes under the influence of anthropogenic pressure described, among other things, as the changes in land use. The greater anthropogenic pressure, the bigger changes of ecological stability and ecological significance. These changes are particularly significant for the areas used primarily as agricultural productive space. Special attention should be paid to the places located in the periphery of cities. The anthropogenic pressure is bigger there and the transformations in e.g. land use are also considerable (Poniży, 2008).

What is worth noting - in case of two analysed places situated peripherally in relation to Krakow - the directions of changes of the indexes do not confirm the changes that result from the direct analysis of land use. Because the indexes noted here indicate the growth of ecological stability with simultaneous decrease of anthropogenic areas (to which the presented method classifies also arable lands) in case of the place adjacent directly to the borders of Krakow agglomeration. Different situation takes place in the second surveyed object - Kaszów. The agricultural character decided about the lower value of the coefficient of ecological stability (CES) and the growing value of CAI (the anthropogenic influence coefficient) despite several-kilometers distance from administrative borders of Krakow.

\section{CONCLUSION}

The presented methodology of determining the values of bio-indexes in the surveys of historical changes of land use allowed not only to determine the rate of anthropogenic interference but also the level of ecological stability. Presented values of indexes indicate that anthropogenic transformations are influenced most of all by the change of the area of farmland which according to the definition of these coefficients are treated as the area transformed anthropogenically.

The surveys of CES and CAI indexes did not reveal the impact of urban agglomeration on the changes of ecological significance or the anthropogenic influence coefficient. The greater ecological stability was revealed in Kryspinów situated in close vicinity of Krakow in relation to more distant agricultural place of Kaszów. Nevertheless, the direction of transformations of farmland indicates the bigger increase of built-up and urbanized areas in adjacent to Krakow Kryspinów with simultaneous decrease of the area of arable lands. The surveys reveal that the share of arable land was growing with increasing suitability of an area for agriculture and their share even after 170 years of historical analysis is comparable as it is in Kaszów. In this place, the area of built-up areas slightly increased.

The results of the study can be used by public authorities, citizens and governing bodies to form a system of measures to calculate environmental potential and modelling changes which ensure the environmental protection and sustainable development of rural areas.

\section{REFERENCES}

1. Andrzejewski, R., Weigle, A. (eds.) 2003. Różnorodność biologiczna Polski. (Bio-diversity in Poland). Wyd. Narodowego Funduszu Ochrony Środowiska. Warszawa. p. 284 [In Polish].

2. Bański, J., Mazur, M. 2016. Classification of rural areas in Poland as an instrument of territorial policy. Land Use Policy, No. 54, pp. 1-17. https://doi.org/10.1016/j.landusepol.2016.02.005

3. Baran-Zgłobicka, B., Zgłobicki, W. 2012. Mosaic landscape of SE Poland:should we preserve them? Agroforestry Systems, Vol. 85, pp. 351-365. https://doi.org/10.1007/s10457-011-9436-x

4. Bartkowski, T. 1981. Transurbacje miast Wielkopolski i niektóre zagadnienia przestrzenno-planistyczne ich rozwoju oraz zastosowanie do nich niektórych metod fizjografii urbanistycznej. (Transurbations of the cities of Wielkopolska and some spatialplanning issues of their development with using the for certain methods of urban physiography) Wydawnictwo Naukowe UAM, Seria Geografia 22, Poznań. [In Polish]

5. Bičík, I. 1991. On the methodology of land use assessment. [In:] Bičík I. et al. Geografie zemědělstvi II. Charles University in Prague, Prague, pp. 77-90.

6. Bičík, I., Himiyama, Y., Feranec, J., Štych, P. 2012. Land use/cover changes in selected regions in the world. Vol. VII, IGU Commission on LUCC, Charles University in Prague, Prague.

7. Bičík, I., Himiyama, Y., Feranec, J., Kupková, L. 2014. Land use/cover changes in selected regions in the world. Vol. IX, IGU Commission on LUCC, Charles University in Prague, Prague. 


\section{Proceedings of the $8^{\text {th }}$ International Scientific Conference Rural Development 2017}

8. Bucała, A., Starkel, L. 2012. Wpływ gwałtownych i powolnych zmian użytkowania ziemi na przekształcenia środowiska polskich Karpat. (Influence of violent and slow changes of land use on the transformation of the Polish Carpathians), Wyd. Instytut Geografii i Przestrzennego Zagospodarowania PAN, Warszawa. [In Polish]

9. Bürgi, M., Straub, A., Gimmi, U., Salzmann, D. 2010. The recent landscape history of Limpach valley: Switzerland: Considering three empirical hypotheses on driving forces of landscape change. Landscape Ecology, No 25, pp. $287-297$. https://doi.org/10.1007/s10980-009-9412-2

10. Bürgi, M., Hersperger, A. M., Schneeberger, N. 2005. Driving forces of landscape change - Current and new directions. Landscape Ecology, Vol. 19, Iss. 8, pp. 857-868. https://doi.org/10.1007/s10980-005-0245-3

11. Eiter, S., Fjellstad, W., Stokstad, G. 2014. Agricultural landscapes of Norway: Farmland continuity and change, and their driving forces. (In:) Bicik I., Himijama Y., Feranec J., Kupkova L. (Editors) Land Use/ Cover Changes in Selected Regions in the World. Vol. IX, IGU Commission on LUCC, Charles University in Prague, Prague.

12. Harvey, F., Kaim, D., Gajda, A. 2014. Analysis of historical change using cadastral materials in the Carpathian Foothills. European Journal of Geography, Vol. 5, No 3, pp. 6-21.

13. Hernik, J., Gawroński, K., Dixon-Gough, R. 2013. Social and economic conflicts between cultural landscapes and rural communities in the English and Polish systems. Land Use Policy, Vol. 30, Iss. 1, pp. 800-813. https://doi.org/10.1016/j.landusepol.2012.06.006

14. Kabrda, J. 2004. Influence of natural conditions on land use in the Vysočina region and its changes since the mid-19th century. Acta Universitatis Carolinae Geographica, No. 2, pp. 15-38.

15. Kalnay, E., Cai, M. 2000. Impact of urbanization and land-use change on climate. Nature, Vol. 423, Issue 6939, pp. 528-531.

16. Lamlin, E.F., Rounsevell, M.D.A., Geist, H.J. 2000. Are agricultural land-use models able to predict changes inf land-use intensity? Agriculture Ecosystems and Environment, No 82, pp. 321-331.

17. Long, H., Heilig, G.K., Li, X., Zhang, M. 2007. Socio-economic development and land-use change: Analysis of rural housing land transition in the Transect of the Yangtse River, China. Land Use Policy, No 24, pp. 141-153. https://doi.org/10.1016/j.landusepol.2005.11.003

18. Louca, M., Vogiatzakis, I.N., Moustakas, A. 2015. Modelling the combined effects of land use and climatic changes: Coupling bioclimatic modelling with Markov-chain Cellular Automata in a case study in Cyprus. Ecological Informatics, No. 30, pp. 241-249. https://doi.org/10.1016/j.ecoinf.2015.05.008

19. Mather, A.S. 2002. The reversal of land-use trends: the beginning of the reforestation of Europe. [In:] Bičík I. (eds.) Land Use/ Cover Changes in the Period of Globalization. Proceedings of the IGU-LUCC International Conference, Prague, 2001, Charles University in Prague, Prague, pp. 23-30.

20. Noszczyk, T., Rutkowska, A., Hernik, J. 2017. Determining Changes in Land Use Structure in Małopolska Using Statistical Methods. Polish Journal of Environmental Studies, Vol. 26, No. 1, pp. 211-220. https://doi.org/10.15244/pjoes/64913

21. Pohl, J. 1978. Związki rolniczego użytkowania ziemi ze środowiskiem przyrodniczym we wschodniej części Karpat. (Relationships of agricultural land use with natural environment in the eastern part of the Carpathians), Prace Geograficzne, z. 125, pp. 123-143. [In Polish]

22. Poławski, Z. 2009. Land use changes in Poland during last two centuries. Teledetekcja Środowiska, No. 42, pp. 69-82, [In Polish]

23. Poniży, L. 2008. Presja urbanizacyjna i jej wpływ na zmiany przestrzennej struktury użytkowania ziemi na wybranych obszarach podmiejskich Poznania. (Suburban pressure and its influence on land use changes on the example of choosen areas in Poznań vicinity) Problemy Ekologii Krajobrazu, T. XXII. 335-342. [In Polish].

24. Regulation... 2001 - Rozporządzenie Ministra Rozwoju Regionalnego i Budownictwa w sprawie ewidencji gruntów i budynków z dnia 29 marca 2001 r. (Dz.U. z 2001 r. Nr 38, poz. 454 z późniejszymi zmianami). The Regulation of the Minister of Regional Development and Construction in registration of lands and buildings on 29 March 2001 (Dz.U. from 2001, No. 38, pos. 454 with later changes). [In Polish]

25. Schaldach, R., Alcamo, J., Koch J., Koelking, C., Lapola, D.M., Schuengel, J., Priess, J.A. 2011. An integrated approach to modelling land-use change on continental and global scales. Environmental Modelling and Software, No. 26, pp. $1041-1051$. https://doi.org/10.1016/j.envsoft.2011.02.013

26. Sokołowski, D. 1999. Zróżnicowanie zbioru małych miast i większych osiedli wiejskich w Polsce w ujęciu koncepcji kontinuum wiejsko-miejskiego. (Diversity of the set of small towns and bigger rural settlements in Poland in terms of the concept of ruralurban continuum) Wyd. UMK, Toruń. [In Polish]

27. Springer, F. 2013. Wanna z kolumnadą. (The bathtub with a colonnade) Wyd. Czarna, Warszawa. [In Polish]

28. Staniak, M. 2009. Zrównoważony rozwój obszarów wiejskich w aspekcie środowiskowym. (Sustainable development of rural areas in the environmental aspect,) Woda - Środowisko - Obszary Wiejskie. T.9. Z.3 (27), s.187-194. [In Polish]

29. Veldkamp, A., Verburg, P.H. 2004. Modelling land use change and environmental impact. Journal of Environmental Management, No 72, pp. 1-3.https://doi.org/10.1016/j.jenvman.2004.04.004

30. Zydroń, A., Hausa, P. 2010. Analysis of changes in the structure of land use and ownership after transformation of political and economic system in Poland in 1989 based on selected communes in the Wielkopolska Region. Rocznik Ochrona Środowiska (The Yearbook Environment Protection), Vol. 12, pp. 909-925, [In Polish] 